\title{
DETERMINATION OF DEFENSE MECHANISM IN Phaseolus Trilobus Ait. SEEDLINGS TREATED UNDER UV-B RADIATION
}

\author{
K.C. RAVINDRAN, A. INDRAJITH, V. BALAKRISHNAN, K. VENKATESAN \\ and G. KULANDAIVELU ${ }^{1}$ \\ Department of Botany, Annamalai University, Annamalainagar 608 002, Tamil Nadu, India \\ ${ }^{1}$ Department of Plant Sciences, School of Biological Sciences, Madurai Kamaraj University,
} Madurai 625 021, Tamil Nadu, India

(Received 14 February, 2007; accepted 3 March, 2008)

\begin{abstract}
Field studies were conducted to determine the role of defense mechanism in various parameters associated with plant protection subjected to UV-B radiation in Phaseolus trilobus Ait. commonly used as green manure and fodder. Spectrophotometric analysis showed that UV-B radiation decreases the chlorophyll content and increased the amount of UV-B absorbing compounds such as anthocyanins and flavonoids. Other UV-induced alterations included reduction in fresh weight and leaf area. However, wrinkling of leaves and increased leaf thickness was observed in UV-B treated seedlings. The antioxidant enzymes were unaffected and showed enhanced activity, except catalase in UV-B treated seedlings. These results suggest that, in general, UV-B radiation caused oxidative damage. However, plants have evolved complex mechanisms to scavenge the active oxygen species and thereby protect the cellular membrane, pigment and organelle.
\end{abstract}

Key Words: Anthocyanin, catalase, chlorophyll, phenol, superoxide dismutase, UV-B radiation

\section{RÉSUMÉ}

Des études sur le terrain ont été conduites pour déterminer le rôle du mécanisme de défense dans divers paramètres liés à la protection des plantes soumises au rayonnement UV-B dans le Phaselus trilobus Ait. communement utilisé comme engrais verts et fourrage. L'analyse spectrophotométrique a prouvé que le rayonnement UV-B diminue le contenu en chlorophylle et augmente la quantité de composés absorbant l'UV-B tels que des anthocyanines et des flavonoïdes. D'autres altérations d'UV-induits ont inclus la réduction de poids à l'état frais ainsi que de la surface foliaire. Cependant, on a observé des feuilles ridées et un accroissement en épaisseur de feuilles des plantules traitées par UV-B. Les enzymes antioxydantes n'étaient pas affectées et ont montré une augmentation de leur activité, à l'exception de la catalase dans les plantules traitées au UV-B. Ces résultats suggèrent que, en général, le rayonnement UV-B cause le dommage oxydative. Cependant, les plantes ont développé des mécanismes complexes pour se débarrasser des espèces d'oxygène actif et ainsi protéger la membrane cellulaire, le pigment et organelle.

Mots Clés: Anthocyanine, catalase, chlorophylle, phénol, superoxyde dismutase, rayonnement UV-B

\section{INTRODUCTION}

Ozone absorbs radiation appreciably at wavelengths shorter than $300 \mathrm{~nm}$. A reduction of the stratospheric ozone layer results in a very specific increases in short wavelength solar ultraviolet radiation (UV-B 280-320 nm). The concerns over the depletion of the ozone layers arose simultaneously in the mid 1970's from observed conditions and theoretical speculation. 
The average ozone column decreased by about $10 \%$ from mid 1991 to the beginning of 1993 in the northern hemisphere. A $10 \%$ depletion in stratospheric ozone corresponds to a $20 \%$ increase in the fluence of biologically damaging UV-B radiation. The impacts of UV-B radiation on vegetation has been extensively studied through growth chamber, green house and field experiments. These studies conclude that UV-B radiation may affect terrestrial plants through changes in plant growth, photosynthesis and transpiration, pollination and flowering, yield, DNA and cellular damage, competitive balance in a community, susceptibility to diseases, environmental stress and pollution (Tevini and Teramura, 1989). The aim of present study was to investigate the role of defense mechanisms in UV-B treated Phaseolus trilobus seedlings.

\section{MATERIALS AND METHODS}

Plant material and UV dosage. Seeds of $P$. trilobus were sown in several plastic trays, containing a soil mixture of sand (70\%) and compost (30\%). After 4 days growth, the plants were transferred to the field. Seedlings were watered periodically and care was taken to minimise nutritional deficiency and infection on seedlings. In the field, UV-B radiation was provided for $2 \mathrm{~h}$ (11.00 a.m. to 1.00 p.m.) per day by Philips sunlamps (Philips TL 20 W/12, N.V. Philips Gloelampenfabriekan, Holland) centred at solar noon and oriented in an east - west direction. The UV-B irradiance was weighed using generalised plant response action spectrum of Caldwell (1971) normalised at $300 \mathrm{~nm}$. The biologically effective level of UV-B radiation was $12.2 \mathrm{~kJ} \mathrm{~m}^{-2} \mathrm{~d}^{-1}$.

Measurement of growth characters. Total length of the seedlings and fresh weight were measured immediately after removing the seedlings from the experimental field. Leaf area was calculated using the Li Cor 3100 leaf area meter (LICOR, Model LI-3100, Lincoln, USA). Dry weight of the seedlings was determined after drying at $80{ }^{\circ} \mathrm{C}$ for $24 \mathrm{~h}$. Leaf thickness was measured by taking leaf bits of $0.3 \times 1.0 \mathrm{~cm}$ cut from the middle intervenal region of upper leaves. The cross sections of leaves were prepared by using a rotary microtome and observed under compound microscope.

Determination of photosynthetic pigments. Chlorophyll contents was estimated by following the procedure of Moran and Porath (1980) using the formulae suggested by Inskeep and Bloom (1985). Fresh leaf discs of $100 \mathrm{mg}$ were cut and placed in a test tube containing $10 \mathrm{ml}$ of N,N'dimethylformamide (DMF) and stored for $24 \mathrm{~h}$ at $4{ }^{\circ} \mathrm{C}$. The coloured supernatant was used for chlorophyll and carotenoid estimation. By reading the absorbance at 647 and $666 \mathrm{~nm}$ in a spectrophotometer with DMF as blank for chlorophyll and 480, 647 and $666 \mathrm{~nm}$ were used to find the corrected absorbance for carotenoids (Ikan, 1969).

Determination of UV absorbing pigments. Anthocyanin content was extracted in acidified methanol (1:99 HCI: Methanol) in $100 \mathrm{mg}$ of leaf material. Extract was kept at $0{ }^{\circ} \mathrm{C}$ for 24 hours. After 24 hours, the content was made up to $10 \mathrm{ml}$ and the absorbance was read at $530 \mathrm{~nm}$, as described by Mancinelli et al. (1975). Flavonoids were extracted and quantified as described previously (Mirecki and Teramura, 1984). Hundred milligrammes of leaves were placed in $80 \%$ acidified methanol (Methanol: Water: $\mathrm{HCI}-$ $80: 20: 1)$ for $12 \mathrm{~h}$ in dark at $4{ }^{\circ} \mathrm{C}$ to extract flavonoids. Absorbance was read at $315 \mathrm{~nm}$. Total phenols were estimated by following the method of Bray and Thorpe (1954).

Enzyme preparations and assays. Catalase (CAT, EC 1.11.1.6) activity was measured by the method of Machly and Chance (1959). One gramme of leaf tissue was homogenised in $10 \mathrm{ml}$ of $0.1 \mathrm{mM}$ sodium phosphate buffer, $\mathrm{pH} 7$ and centrifuged at $4{ }^{\circ} \mathrm{C}$ for 10 minutes at $10,000 \mathrm{~g}$. An aliquot of $1 \mathrm{ml}$ of the supernatant of the enzyme extract was added to the reaction mixture containing $1 \mathrm{ml}$ of $0.01 \mathrm{MH}_{2} \mathrm{O}_{2}, 3 \mathrm{ml}$ of $0.1 \mathrm{M}$ sodium phosphate buffer, $\mathrm{pH}$ 6.8. The reaction was stopped after an incubation of 5 minutes at $20{ }^{\circ} \mathrm{C}$ by addition of $10 \mathrm{ml}$ of $1 \% \mathrm{H}_{2} \mathrm{SO}_{4}$. the acidified medium without or with the enzyme extract was titrated against $0.005 \mathrm{~N} \mathrm{KMnO}_{4}$. 
Extraction and assay methods for peroxidase, polyphenol oxidase and superoxide dismutase. One gramme of leaves were homogenised with $20 \mathrm{ml}$ of ice cold extraction medium containing 2 $\mathrm{mM} \mathrm{MgCl}_{2}, 1 \mathrm{mM}$ EDTA, $10 \mathrm{mM}$ bMercaptoethanol, 7\% PVP and $10 \mathrm{mM}$ sodium metabisulphate. The homogenate was stained through two layers of cheesecloth and centrifuged at 10,000 g for 15 minutes and the supernatant was made up to $20 \mathrm{ml}$ with the same buffer and it was used as the source of enzyme.

Peroxidase (POX, EC 1.11.1.7) activity was assayed by the method of Kumar and Khan (1982). Polyphenol oxidase (PPO, EC 1.10.3.1) was determined as described by Kumar and Khan (1982). Superoxide dismutase (SOD, EC 1.15.1.1) activity was determined by the method proposed by Beauchamp and Fridovich (1971). Phenylalanine ammonialyase (PAL, EC 4.3.1.5) activity was determined by following the method of Amrhein and Zenk (1971).

Statistical analyses. Analysis of variance (ANOVA) was performed on the data using a linear model and assessing the effect of treatment (control and UV-B). Means were compared using Student's test.

\section{RESULTS}

Growth. Morphological changes such as bronzing, wringling and chloretic lesions were observed in $P$. trilobus seedlings after four days of UV-B exposure. Shoot length was stunted (26.4\%) under UV-B radiation. Accordingly, a decrease in fresh weight (27\%) and dry weight (51\%) were also observed after four days of UVB radiation. UV-B exposure also significantly reduced the leaf area (30\%) when compared to control seedlings. In comparison with control plants, UV-exposed seedlings increased the leaf thickness $(16.7 \%)$ and also showed curling of leaves (Table 1).

Photosynthetic pigments. On fresh mass basis, total chlorophyll content was reduced nearly $26 \%$ in UV-B exposure compared to control seedlings on fourth day. However, 6\% increase in photosynthetic pigment was observed in UV-B exposure plants during first day. Compared to chlorophyll, carotenoids are less affected by UV$\mathrm{B}$ radiation. The carotenoid content was also found to be reduced (13\%) in UV-B treated seedlings (Table 2).

UV-absorbing pigments. Unlike photosynthetic pigments, UV-B radiation induces a class of UV absorbing pigments such as anthocyanins and flavonoids. It was observed that UV-B exposure seedlings showed increased trend in synthesis of anthocyanin (186\%), flavonoid (142\%) and phenol content $(40 \%)$. The synthesis of anthocyanin was higher when compared to flavonoid in UV-B exposure seedlings (Table 2).

TABLE 1. Effect of UV-B radiation on growth parameters of $P$. trilobus seedlings

\begin{tabular}{|c|c|c|c|c|c|c|}
\hline Day(s) & Treatment & $\begin{array}{l}\text { Shoot length } \\
(\mathrm{cm})\end{array}$ & $\begin{array}{l}\text { Fresh weight } \\
\left(\text { g plant }^{-1}\right)\end{array}$ & 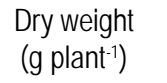 & $\begin{array}{l}\text { Leaf area } \\
\left(\mathrm{cm}^{2} \text { plant }^{-1}\right)\end{array}$ & $\begin{array}{l}\text { Leaf thickness } \\
(\mu)\end{array}$ \\
\hline \multirow[t]{2}{*}{1} & Control & $5.10 \pm 0.25$ & $1.03 \pm 0.05$ & $0.162 \pm 0.08$ & $1.08 \pm 0.05$ & $0.008 \pm 0.04$ \\
\hline & UV-B & $5.17 \pm 0.25$ & $1.05 \pm 0.05$ & $0.150 \pm 0.07$ & $1.10 \pm 0.05$ & $0.009 \pm 0.04$ \\
\hline \multirow[t]{2}{*}{2} & Control & $6.20 \pm 0.31$ & $1.41 \pm 0.07$ & $0.200 \pm 0.10$ & $1.34 \pm 0.06$ & $0.010^{*} \pm 0.05$ \\
\hline & UV-B & $5.75 \pm 0.28$ & $1.34 \pm 0.06$ & $0.163 \pm 0.08$ & $1.28 \pm 0.06$ & $0.011 \pm 0.06$ \\
\hline \multirow[t]{2}{*}{3} & Control & $8.30 \pm 0.42$ & $1.64 \pm 0.08$ & $0.266^{*} \pm 0.13$ & $1.36^{*} \pm 0.07$ & $0.012^{*} \pm 0.06$ \\
\hline & UV-B & $6.78 \pm 0.33$ & $1.36 \pm 0.07$ & $0.173 \pm 0.09$ & $1.09 \pm 0.05$ & $0.014^{\star} \pm 0.07$ \\
\hline \multirow[t]{2}{*}{4} & Control & $10.60 * \pm 0.53$ & $2.11^{*} \pm 0.10$ & $0.354 \pm 0.17$ & $1.39^{\star} \pm 0.07$ & $0.014^{\star} \pm 0.07$ \\
\hline & UV-B & $7.80 \pm 0.39$ & $1.54 \pm 0.08$ & $0.183 \pm 0.09$ & $0.97 \pm 0.04$ & $0.016^{\star} \pm 0.08$ \\
\hline
\end{tabular}

Results are means \pm S.E of 5 replicates. Significant level $(P)$ for Student ' $t$ ' test is shown of ${ }^{*}<0.05$ 
TABLE 2. Effect of UV-B radiation on chlorophyll, carotenoid, anthocyanin, flavonoid and phenol in P. trilobus seedlings

\begin{tabular}{|c|c|c|c|c|c|c|}
\hline Day(s) & Treatment & $\begin{array}{r}\text { Chlorophyll } \\
\text { (mg g }{ }^{-1} \text { fr. wt.) }\end{array}$ & $\begin{array}{c}\text { Carotenoid } \\
\text { (mg g-1 fr. wt.) }\end{array}$ & $\begin{array}{l}\text { Anthocyanin } \\
\left(A_{530} g \text { fr. wt. }\right)\end{array}$ & $\begin{array}{c}\text { Flavonoid } \\
\left(A_{315} g \text { fr. wt. }\right)\end{array}$ & $\begin{array}{c}\text { Phenol } \\
\text { (mg g } \mathrm{g}^{-1} \text { fr. wt.) }\end{array}$ \\
\hline 1 & $\begin{array}{l}\text { Control } \\
\text { UV-B }\end{array}$ & $\begin{array}{l}2.52 \pm 0.12 \\
2.67 \pm 0.13\end{array}$ & $\begin{array}{l}0.12 \pm 0.05 \\
0.12 \pm 0.05\end{array}$ & $\begin{array}{l}0.03 \pm 0.01 \\
0.04^{*} \pm 0.02\end{array}$ & $\begin{array}{l}0.21 \pm 0.10 \\
0.23 \pm 0.11\end{array}$ & $\begin{array}{l}1.12 \pm 0.05 \\
1.20 \pm 0.06\end{array}$ \\
\hline 2 & $\begin{array}{l}\text { Control } \\
\text { UV-B }\end{array}$ & $\begin{array}{l}3.47 \pm 0.17 \\
3.30 \pm 0.16\end{array}$ & $\begin{array}{l}0.17 \pm 0.08 \\
0.16 \pm 0.08\end{array}$ & $\begin{array}{l}0.04 \pm 0.02 \\
0.06^{\star} \pm 0.03\end{array}$ & $\begin{array}{l}0.24 \pm 0.12 \\
0.34 \pm 0.16\end{array}$ & $\begin{array}{l}1.34 \pm 0.06 \\
1.59 \pm 0.07\end{array}$ \\
\hline 3 & $\begin{array}{l}\text { Control } \\
\text { UV-B }\end{array}$ & $\begin{array}{l}5.31^{*} \pm 0.26 \\
4.47 \pm 0.22\end{array}$ & $\begin{array}{l}0.24^{*} \pm 0.11 \\
0.21^{*} \pm 0.66\end{array}$ & $\begin{array}{l}0.05 \pm 0.03 \\
0.11^{*} \pm 0.05\end{array}$ & $\begin{array}{l}0.28 \pm 0.14 \\
0.57^{*} \pm 0.28\end{array}$ & $\begin{array}{l}1.69 \pm 0.08 \\
2.25 \pm 0.11\end{array}$ \\
\hline 4 & $\begin{array}{l}\text { Control } \\
\text { UV-B }\end{array}$ & $\begin{array}{l}6.81^{*} \pm 0.35 \\
5.56^{*} \pm 0.25\end{array}$ & $\begin{array}{l}0.29^{\star} \pm 0.14 \\
0.25^{\star} \pm 0.04\end{array}$ & $\begin{array}{l}0.06 \pm 0.04 \\
0.17^{\star} \pm 0.08\end{array}$ & $\begin{array}{l}0.31 \pm 0.15 \\
0.75^{\star} \pm 0.37\end{array}$ & $\begin{array}{l}1.78 \pm 0.09 \\
2.50^{\star} \pm 0.12\end{array}$ \\
\hline
\end{tabular}

Results are means \pm S.E of 5 replicates. Significant level $(P)$ for Student ' $t$ ' test is shown of ${ }^{*} P<0.05$

Enzymes. Plants have the capacity to develop various means of protection from the deleterious effects of UV-B radiation. The present work shows that UV-B exposure decreased the activities of CAT and increased the POX, PPO, PAL and SOD. It is estimated that after four days of treatment, CAT activity was reduced to $24 \%$ and POX (88\%), PPO (57\%), PAL (56\%) and SOD (55\%) activities are increased in UV-B exposure seedlings, when compared to control (Table 3).

\section{DISCUSSION}

After four days of UV-B exposure, seedlings showed greater reduction in morphology and growth. Plant stunting is common in UV-B exposure (Santos et al. , 1993). It is primarily due to short internodes and reductions in node number. UV-B induced stunting could be specifically due to accumulation of flavins, which act as UV-B photoreceptors and which are responsible for inhibition of internode elongation. There are reports correlating the tolerance of the species to their ability to increase leaf thickness in response to UV-b exposure (Deckymyn and Impens, 1999). Our results showed that $P$. trilobus plants responded to UV-B radiation by developing thicker leaves and increasing in them the level of flavonoids and anthocyanins are considered as an important responses of UV-B tolerant plants.
In the present study, UV-B exposure significantly reduced the chlorophyll content. In an extensive survey of many plant species, such a trend was indeed evident (Cuadra et al., 2004). The reduction in chlorophyll level might be due to inhibition of biosynthesis or degradation of chlorophyll and their precursors. Accumulation of chlorophyllides 'a' and 'b' decreases the chlorophyll levels. Jordan et al. (1991) explained that the decline in chlorophyll level might be due to inhibition of cab gene, which codes for chlorophyll protein. Compared to chlorophyll, carotenoids are less affected by UV-B radiation. Less inhibition of carotenoids is suggested to be due to their photoprotective role in the photosynthetic apparatus (Middelton and Teramura, 1993). Both carotenoids and flavonol glycosides are known to have protective roles in safeguarding the photosynthetic apparatus and subcellular organelles from UV damage. The biosynthenthic pathway of carotenoids might be less influenced by UV-B than that of chlorophyll (Tevini et al., 1981). The carotenoids are involved in light harvesting and photoprotection of chloroplast from the effects of visible and UV-B radiation.

Anthocyanin concentration was significantly increased in UV-B radiation treatment. A48 hours continuous irradiation of UV-b radiation increased the anthocyanin at 4 fold-levl in Vigna (Kulandaivelu et al., 1989). Accumulation of 
TABLE 3. Effect of UV-B radiation on catalase, peroxidase, polyphenol oxidase, phenylalanine ammonialyase and superoxide dismutase in P. trilobus seedlings

\begin{tabular}{|c|c|c|c|c|c|c|}
\hline Day(s) & Treatment & 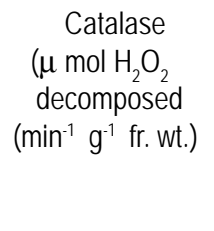 & $\begin{array}{l}\text { Peroxidase } \\
\text { ( } \mu \text { mol } \\
\text { purpurogallin } \\
\text { formed } \\
\min ^{-1} \mathrm{~g}^{-1} \text { fr. wt.) }\end{array}$ & $\begin{array}{l}\text { Polyphenol } \\
\text { oxidase } \\
\text { ( } \mu \text { mol } \\
\text { purpurogallin } \\
\text { formed } \\
\mathrm{min}^{-1} \mathrm{~g}^{-1} \mathrm{fr} \text {. wt.) }\end{array}$ & $\begin{array}{l}\text { Superoxide } \\
\text { dismutase } \\
\text { ( } \mu \text { mol annamic } \\
\text { acid formed } \\
\left(g^{-1} h^{1} \text { fr. wt.) }\right.\end{array}$ & $\begin{array}{l}\text { Phenylalanine } \\
\text { ammonialyase } \\
\text { (units } \mathrm{h}^{-1} \mathrm{mg}^{-1} \\
\text { protein fr. wt.) }\end{array}$ \\
\hline \multirow[t]{2}{*}{1} & Control & $9.32 \pm 0.46$ & $30.12 \pm 1.5$ & $25.31 \pm 1.2$ & $13.52 \pm 0.6$ & $10.46 \pm 0.5$ \\
\hline & UV-B & $8.90 \pm 0.44$ & $34.78 \pm 1.7$ & $27.68 \pm 1.3$ & $14.89 \pm 0.7$ & $11.44 \pm 0.5$ \\
\hline \multirow[t]{2}{*}{2} & Control & $12.62 \pm 0.63$ & $32.68 \pm 1.6$ & $28.66 \pm 1.4$ & $17.68 \pm 0.8$ & $13.32 \pm 0.6$ \\
\hline & UV-B & $11.47 \pm 0.57$ & $44.55^{\star} \pm 2.2$ & $34.74 \pm 1.7$ & $20.74 \pm 1.0$ & $16.36 \pm 0.8$ \\
\hline \multirow[t]{2}{*}{3} & Control & $14.36^{\star} \pm 0.71$ & $35.12 \pm 1.7$ & $30.34 \pm 1.5$ & $20.34 \pm 1.0$ & $16.78 \pm 0.8$ \\
\hline & UV-B & $11.87 \pm 0.59$ & $58.30^{*} \pm 2.9$ & $43.04^{\star} \pm 2.1$ & $28.64^{\star} \pm 1.4$ & $24.26^{\star} \pm 1.2$ \\
\hline \multirow[t]{2}{*}{4} & Control & $17.41 * \pm 0.87$ & $38.41 \pm 1.9$ & $33.01^{*} \pm 1.6$ & $23.60^{*} \pm 1.1$ & $20.31^{*} \pm 1.0$ \\
\hline & UV-B & $13.15^{\star} \pm 0.65$ & $72.25^{\star} \pm 3.6$ & $51.84^{*} \pm 2.5$ & $36.73^{\star} \pm 1.8$ & $32.10^{*} \pm 1.6$ \\
\hline
\end{tabular}

Results are means $\pm S$. E of 5 replicates. Significant level $(P)$ for Student ' $t$ ' test is shown of ${ }^{*} P<0.05$

anthocyanin and other UV absorbing compounds in the upper epidermis could act as solar screens by absorbing UV before it reaches sensitive targets such as chloroplast (Flint et al., 1985). Similar to anthocyanin, flavonoid concentration was also increased in UV-B treated seedlings. This trend in accumulation of flavonoids were studied by Premkumar and Kulandaivelu (2001). Plants are able to prevent the dangerous effects of UV-B radiation by synthesizing flavonoids, a class of UV absorbing compounds located mainly in the epidermis and acting as an internal filter. In higher plants, flavonoids and other phenyl propanoid derivatives such as sinapet esters accumulate in large quantities in the vacuoles of epidermal cells, effectively attenuate the UV component of sunlight with minimum effects on the visible region of the spectrum (Mazza et al., 2000). According to Tevini et al. (1991), flavonoid accumulation is regarded as a defense mechanism in higher plants to provide protection against UV$\mathrm{B}$ radiation. Hence, it is concluded that the UV-B treated seedlings may activate a defense mechanism against UV-B damage by increasing flavonoid.
Phenols are carbon-based secondary compounds, whose concentrations should also depend on the competition for the allocation of photosynthetically fixed carbon to growth or defense. Phenols accumulate in plant tissues during stress and due to oxidant damage (Howell, 1974).

In the present study, catalase showed an overall reduction in response to the supplemental UV-B radiation. This reduction trend in catalase activity under UV-B radiation was also observed by Rao et al. (1996). Catalase is the most efficient antioxidant enzyme, which protects plants by scavenging free radicals and $\mathrm{H}_{2} \mathrm{O}_{2}$. This may explain the low activity of catalase observed in the present study. Catalase, in conjunction with other antioxidants, are known to reduce the concentration of $\mathrm{O}_{2}^{-}, \mathrm{OH}^{-}$and $\mathrm{H}_{2} \mathrm{O}_{2}$ (Bowler et al., 1992). Catalase activity was reduced with a simultaneous increase in peroxidase activity (Rao et al., 1996). Nandi et al. (1984) suggested that the inversed relationship between two enzymes due to the tetrameric molecules of catalase might disintegrate in vivo into monomeric units with peroxidase activity. 
Plants have the capacity to develop various means of protection from the deleterious effects of UV-B radiation. POX, PPO, SOD and PAL are key enzymes for antioxidant defense system for scavenging $\mathrm{H}_{2} \mathrm{O}_{2}$. In the present study CAT showed an overall decrease; however, the activities of other enzymes increased in UV exposure seedlings.

The increase in peroxidase activity might be due to an increase in $\mathrm{H}_{2} \mathrm{O}_{2}$ production probably as a result of induced SOD activity during the UV-B radiation (Sharma et al., 1998). Further, peroxidases are believed to utilise phenolic compounds as co-substrate (Otter and Polle, 1994). This fact was confirmed by the presence of higher phenolic content observed in this study. The presence of increased PPO is responsible for the oxidation of phenolic compound in the present study. Similar results were reported by Sheen and Calvert (1969).

PAL activity was also increased under UV-B exposure. Studies in cucumber (Krizek et al., 1993) have shown that exposure of seedlings to supplemental UV-B radiation caused 78\% increase in the activity of PAL. PAL is important in regulating flavonoid biosynthesis and is transcriptionally induced UV-radiation (Hahlbrock and Scheel, 1989). Further, increased PAL activity was associated with accumulation of flavonoids as well as anthocyanin in UV-B treated plants. Thus, it concluded that, increase in PAL activity stimulates the synthesis of anthocyanin and flavonoids. Dubey and Guruprasad (1999) also suggested that the enhancement of PAL is due to de novo synthesis of the enzyme parallel to anthocyanin formation.

SOD showed a linear increase in activity throughout the study period in UV-B exposure seedlings. Karabourniotis et al. (1995) found that SOD levels of wheat, maize and potato were increased after exposing them to UV-B. The increase in the activity of SOD observed in our study may be a consequence of the production of $\mathrm{O}_{2}^{-}$in leaves during UV-B treatment. SOD catalyses the dismutation reaction of superoxide anions and can be placed in three classes according to their metal co-factor, $\mathrm{Cu}, \mathrm{Zn}, \mathrm{Mn}$ or Fe SOD. Rao et al. (1996) stated that SOD activity by UV-B is due to preferential expression of the $\mathrm{Cu}$ and $\mathrm{Zn}$ SOD 3, 4 and 5 isomers.

\section{CONCLUSIONS}

In general, ultraviolet-B radiation can have a negative impact on growth and development of plants. Our results suggest that $P$. trilobus plants exposed to UV-B radiation undoubtedly activate several defense mechanisms in morphology, anatomy, UV absorbing compounds and also induced the antioxidant defense mechanisms altogether contributing to the maintenance of the structural integrity of the leaf cell components.

\section{ACKNOWLEDGEMENT}

We are thankful to authorities of Annamalai Univerity for providing laboratory facilities.

\section{REFERENCES}

Amrhein, N. and Zenk, M.H. 1971. Untersuchungen Zur Role der Phenylalanin - Ammonium-Lyase bei der Regultion der Flavonoidsynthese in Buchweizen (Fagopyrum esculentum Moench). Z. Pflanzenphysiol. 64:145-168.

Beauchamp, C.O. and Fridovich, I. 1971. Superoxide dismutase: Improved assays and an assay applicable to acrylamide gel. Annals of Biochemistry 44:275-287.

Bowler, C., Van, M. and Inze, M.D. 1992. Superoxide dismutase and stress tolerance. Annals Review of Plant Physiology and Molecular Biology 43:83-116.

Bray, H.G. and Thorpe, W.Y. 1954. Analysis of phenolic compounds of interest in metabolism. In: Methods in Biochemical Analysis. Glick, D. (Ed.), 1: 27-52. Inter Science Publishers Inc., New York.

Caldwell, M.M. 1971. Solar UV-B irradiation and the growth and development of higher plant. In: Photophysiology. Giese, A.C. (Ed.), 6:131171. Academic Press, New York.

Cuadra, R., Herrera, R. and Fajardo, V. 2004. Effects of UV-B radiation on the Patagonian Jaborosa magellanica Brisben. Journal of Photochemistry and Photobiology 76:61-68.

Deckymyn, G. and Impens, I. 1999. Seasonal responses of six Poaceae to differential levels of solar UV-B radiation. Environment and Experimental Botany 41:177-184. 
Dubey, A. and Guruprasad, K.N. 1999. Introduction of anthocyanin synthesis of phenylalanine ammonialyase. Journal of Plant Biology 26:225-229.

Flint, S.D., Jordan, P.W. and Caldwell, M.M. 1985. Plant protective responses to enhanced UV$B$ radiation under field condition: Leaf optical properties and photosynthesis. Journal of Photochemistry Photobiology 41:95-99.

Hahlbrock, K. and Scheel, D. 1989. Physiology and molecular biology of phenyl propanoid metabolism. Annual Review of Plant Physiology and Plant Molecular Biology 40:367.

Howell, R.K. 1974. Phenols, ozone and their involvement in the physiology of plant injury. In: Air Pollution Related to Plant Growth. Dugger, M. (Ed.), Symp. Ser. 3, Washington. pp. $94-1005$.

Ikan, R. 1969. In: Natural Products. A laboratory Guide. Academic Press, New York.

Inskeep, W.P. and Bloom, P.R. 1985. Extinction co-efficient of chlorophyll 'a' and 'b' in N,N'dimethylformamide and $80 \%$ acetone. Plant Physiology 77:483-485.

Jordan, B.R., Chow, W.S., Strid, A. and Anderson, J.M. 1991. Reduction in cab and PsbA RNA transcripts in response to supplementary ultraviolet-B. FEBS Letters 284:1015-1023.

Karabourniotis, G., Kotsabassidis, D. and Manetas, Y. 1995. Trichome density and its protective potential against ultraviolet-B radiation damage during leaf development. Canadian Journal of Botany 73:376-383.

Krizek, D.T., Kramer, G.F., Upadhyaya, A. And Mirecki, R.M. 1993. UV-B response to cucumber seedlings grown under etal halide and high pressure sodium/deluxe lamps. Physiologiae Plantarum 88:350-358.

Kulandaivelu, G., Maragatham, S. and Nedunchexhian, N. 1989. On the possible control of ultraviolet-B induced responses in growth and photosynthetic activities in higher plants. Physiiologiae Plantarum 76:398-404.

Kumar, K.B. and Khan, P.A. 1982. Peroxidase in excised ragi (Eleusine coracana cv. PR 202) leaves during senescence. Indian Journal of Experimental Botany 20:412-416.
Machly, A.C. and Chance, B. 1959. The assay of catalase and peroxidase. In: Methods of Biochemical Analysis. Glick, D. (Ed.), 1:357425. Inter Science Publishers Inc., New York. Mancinelli, A.L., Yang, C.P.H., Lindguist, P., Anderson, O.R. and Rabino, I. 1975. Photoregulation of anthycyanin synthesis III. The action of streptomycin on the synthesis of chlorophyll and anthocyanin. Plant Physiology 55:251-254.

Mazza, C.A., Boccalandro, H.E., Giordano, C.V., Battista, D.B., Scopel, A.L. and Ballare, C.L. 2000. Functional significance and induction by solar radiation of ultraviolet absorbing sun screens in field-grown soybean crops. Plant Physiology 122:117-126.

Middleton, E.M. and Teramura, A.H. 1993. The role of falvonol glycosides and carotenoids in protecting soybean from ultraviolet-B damage. Plant Physiology 103:741-752.

Mirecki, R.M. and Teramura, A.H. 1984. Effects of ultraviolet-B irradiance on soybean V. The dependence of plant sensitivity on the photosynthetic photon flux density during and after leaf expansion. Plant Physiology 74:475-480.

Moran, R. and Porath, D. 1980. Chlorophyll determination in intact tissues using N,N'dimethylformamide. Plant Physiology 65:478479.

Nandi, P.K., Agrawal, M. and Rao, D.N. 1984. SO induced enzymatic changes and ascorbic acid oxidation in Oryza sativa. Water Air Soil Pollution 21:25-32.

Otter, T. and Polle, A. 1994. The influence of apoplastic ascorbate on the activities of cellwall associated peroxidase and NADHoxidases in needless of Norway Spruce (Piceaabies L.). Plant Cell Physiology 35:1231-1238.

Premkumar, A. and Kulandaivelu, G. 2001. Influence of increased solar UV-B radiation on magnesium deficient cowpea seedlings: Changes in growth and foliar constituents. Plant Science 161:1-8.

Rao, M.V., Paliyath, G. and Drmrod, D.P. 1996. Ultraviolet-B and ozone induced biochemical changes in antioxidant enzymes of 
Arabidopsis thaliana. Plant Physiology 110:125-136.

Santos, I., Almedia, J.M. and Salema, R. 1993. Plants of Zea mays L. developed under enhanced UV-b radiation I. Some ultra structural and biochemical aspects. Journal of Plant Physiology 141:450-456.

Sharma, P.K., Anand, P. and Sankhalkar, S. 1998. Oxidative damage and changes in activities of antioxidant enzymes in wheat seedlings exposed to Ultraviolet-B radiation. Current Science 75:359-365.

Sheen, S.J. and Calvert, J. 1969. Studies on polyphenol content activities and isoenzymes of polyphenol oxidase and peroxidase during air-curing in three tobacco types. Plant Physiology 44:199-204.

Tevini, M. and Teramura, A.H. 1989. UV-B effects on terrestrial plants. Journal of Photochemistry and Photobiology 50:479487

Tevini, M., Braun, J. and Fieser, G. 1991. The productive function of the epidermal layer of rye seedling against ultraviolet-B radiation. Journal of Photochemistry and Photobiology 53:329-333.

Tevini, M., Iwanzik, W. and Thoma, U. 1981. Some effects of enhanced UV-B radiation on the growth and composition of plants. Planta 153:388-394. 